\title{
Kan immunsystemet målrettes mot kreft?
}

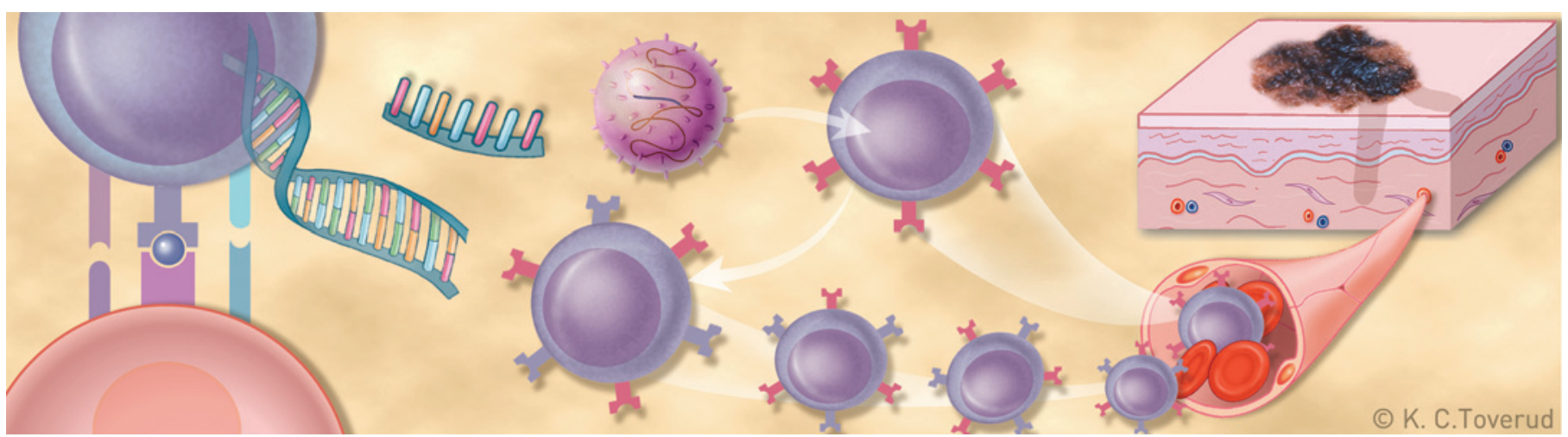

T-cellereseptorer målrettet mot kreft kan settes inn i pasientens T-celler

Tradisjonell kreftbehandling med kjemoterapi og stråling har god effekt ved en rekke kreftformer, men effekten er uselektiv. Forskning på immunsystemet har gitt oss innsikt i hvordan kroppen kvitter seg med infeksiøse agenser og virusinfiserte celler, ofte med minimal skade på friske vev. Lenge før man kjente til mekanismene, lyktes man med å utvikle vaksiner som beskytter mot en rekke vanlige og farlige infeksjoner. Molekylærbiologiske teknikker gjorde det senere mulig å kartlegge reseptorene på B- og T-lymfocytter, som kan gjenkjenne nærmest en hvilken som helst molekylær struktur med en presisjon som aldri vil kunne oppnås med kjemoterapi eller stråling.

I 1984 fikk Köhler og Milstein nobelprisen for oppdagelsen av hvordan såkalte monoklonale antistoffer kan produseres. Oppdagelsen ga store forventninger om et hurtig gjennombrudd i kreftbehandling. Alt man trengte var å finne proteiner som kun fantes på overflaten av kreftceller. Man kunne vaksinere mus med disse og produsere antistoffer for terapi. Dette skulle imidlertid vise seg problematisk. Et av hovedproblemene er at det er svært vanskelig å identifisere «kreftspesifikke» proteiner. Det tok således 22 år fra oppdagelsen til det første monoklonale antistoffet, rettet mot det normale B-celleproteinet CD20 (rituximab), ble godkjent av FDA for bruk til behandling av lymfompasienter.

I dag finnes ni terapeutiske antistoffer godkjent til kreftbehandling, og feltet er et av de raskest voksende innen onkologi (1). Alle de godkjente antistoffene binder normalt uttrykte - ikke kreftspesifikke - proteiner. Terapeutiske antistoffer representer et stort fremskritt, særlig i behandlingen av maligne lymfomer. Antistoffer er imidlertid begrenset av at de kun kan gjenkjenne molekyler på celleoverflaten, mens den store majoriteten av proteiner befinner seg på innsiden. T-celler kan derimot gjenkjenne intracellulære antigener. I 1996 fikk Doherty og Zinkernagel nobelprisen for oppdagelsen av hvordan T-celler spesifikt gjenkjenner peptider fra cellulære proteiner ved at de presenteres på egne vevstypemolekyler på cellens utside. T-celler kan på denne måten blant annet gjenkjenne og effektivt drepe virusinfiserte celler. Dette prinsippet var det god grunn til å tro kunne benyttes ved såkalt terapeutisk vaksinasjon ved kreft.
I tiår har man imidlertid prøvd ut kreftvaksiner der målsettingen er å vekke immunresponser mot proteiner som er overuttrykt i kreftcellene. Konklusjonen så langt er at terapeutiske vaksiner basert på peptider eller proteiner fortsatt er å regne som eksperimentell behandling (1). Hvorfor? Årsakene ligger trolig først og fremst i immunologiske mekanismer som beskytter oss mot autoimmune sykdommer, såkalt immunologisk toleranse. For det første: T-celler som effektivt kan gjenkjenne egne normale celler, fjernes under utviklingen av immunsystemet. Derfor vil tumorassosierte proteiner, som også finnes i egne normale celler, vanligvis ikke oppfattes som fremmede. For det andre: Dersom immunsystemet presenteres for proteiner som er endret og dermed fremmede - som følge av mutasjoner i kreftcellene - i fravcer $a v$ inflammasjon, kan T-cellene som gjenkjenner disse begå selvmord eller bli ikkeresponsive. Kreft gir i liten grad opphav til inflammasjon, og dermed svekkes immunresponsen.

I 2011 fikk Steinmann nobelprisen for oppdagelsen av en liten gruppe celler med spesialoppgave å sparke i gang immunresponser. Nå hadde man langt på vei frarøvet immunsystemet hemmeligheten som knytter gjenkjennelse av fremmed materiale til en effektiv immunrespons. Man fant metoder for å fremstille såkalte dendrittiske celler fra pasienter. Cellene ble fôret med oppmalte kreftceller, proteiner eller mRNA fra tumor og infundert tilbake. Etter et stort antall studier over mange år sitter vi i dag med en enkelt FDA- godkjenning for en cellebasert vaksine for behandling av prostatakreft, vist å øke median overlevelse med fire måneder (1).

Det er altså vanskelig å rette pasientens eget immunsystem mot tumor. Eksempel på et lovende unntak er resultatene ved behandling av metastatisk melanom med antistoffet anti-CTLA-4, som tar bort «bremsene» til T-cellene. Oppfølging etter tre år viste 20,8 \% overlevelse ved antistoffbehandling mot $12,2 \%$ ved standardbehandling. Dette kan tyde på at aktivering av mange nok T-celleresponser mot ulike mål i tumor likevel sammenlagt kan ha en effekt, selv om kanskje hver respons i seg selv er svak. Å la T-cellene løpe løpsk har imidlertid sin pris; opptil $23 \%$ av pasientene opplever alvorlige bivirkninger knyttet til inflammasjon, uten at dette predikerer antitumoreffekt (1). 
Antistoffer lages i dyr, men T-celler fra dyr kan ikke brukes i mennesker. Betyr dette at behandling basert på T-celler ikke har noen fremtid? Svaret er at slik behandling allerede er rutine ved leukemier. Ved allogen hematopoetisk stamcelle-transplantasjon (beinmargstransplantasjon), får pasienten beinmargsstamceller fra en giver (2). Mange er ikke klar over at T-celler som følger med transplantatet, kan være like viktige som stamcellene. Dersom disse fjernes, reduseres behandlingseffekten, og transplanterte pasienter som får tilbakefall av leukemi, kan gå i remisjon ved infusjon av lymfocytter fra donor. Dette er et klart bevis på at T-celler kan drepe kreftceller effektivt. Grunnen er at alle har et stort antall T-celler som kan gjenkjenne cellene fra et annet individ som fremmed. Problemet er at behandlingen er farlig, fordi T-cellene også kan angripe normale celler. Det er imidlertid mulig å isolere T-celler som spesifikt gjenkjenner celletypespesifikke proteiner fra en annen person, ved å benytte seg av forskjeller i proteinsekvens mellom individer (3), eller i vevstypeantigener (HLA) (4). Slik kan kraftige og spesifikke immunresponser oppnås. Man kan identifisere genene som koder for T-cellereseptorene i slike responser. Videre er det nå mulig å overføre gener som koder for T-cellereseptorer og antistoffer målrettet mot kreft, til pasientens T-celler. Flere studier har vist at denne formen for celleterapi kan ha gode effekter ved melanom (5), lymfom og leukemi (1). Her ligger det nye muligheter fremover.

Som det sto om immunterapi i Nature i desember 2011: «After decades of disappointment, the tide has finally changed due to the success of recent proof-of-concept clinical trials.» Immunterapi er kommet for å bli.

\section{Johanna Olweus}

johanna.olweus@medisin.uio.no

Arne Kolstad
Johanna Olweus (f. 1965) er forskningssjef og seksjonsleder for Seksjon for immunologi ved Institutt for kreftforskning, Oslo universitetssykehus, Radiumhospitalet, og professor ved Universitetet i Oslo. Hun leder en forskningsgruppe som søker å utvikle nye immunterapeutiske strategier for kreftbehandling.

Forfatter har fylt ut ICMJE-skjemaet og oppgir følgende interessekonflikter: Hun har en patentsøknad inne for T-cellereseptorer målrettet mot kreft.

Arne Kolstad (f. 1958) er spesialist i onkologi med spesiell kompetanse innen behandling av maligne lymfomer. Han er leder av Norsk lymfomgruppe og Forskningsgruppen for immunterapi ved Oslo universitetssykehus.

Forfatter har fylt ut ICMJE-skjemaet og oppgir ingen interessekonflikter.

\section{Litteratur}

1. Mellman I, Coukos G, Dranoff G. Cancer immunotherapy comes of age. Nature 2011; 480: 480-9.

2. Kolb HJ. Graft-versus-leukemia effects of transplantation and donor lymphocytes. Blood 2008; 112: 4371-83.

3. Falkenburg JH, Marijt WA, Heemskerk MH et al. Minor histocompatibility antigens as targets of graft-versus-leukemia reactions. Curr Opin Hematol 2002; 9: 497-502.

4. Abrahamsen IW, Stronen E, Wälchli S et al. Targeting B cell leukemia with highly specific allogeneic T cells with a public recognition motif. Leukemia 2010; 24: $1901-9$.

5. Morgan RA, Dudley ME, Wunderlich JR et al. Cancer regression in patients after transfer of genetically engineered lymphocytes. Science 2006; 314: 126-9. 